Volume 8. No. 7, July 2020

International Journal of Emerging Trends in Engineering Research

Available Online at http://www.warse.org/IJETER/static/pdf/file/ijeter111872020.pdf

https://doi.org/10.30534/ijeter/2020/111872020

\title{
Prospects of Using Plasma Surfacing to Producing of Layered Materials
}

\author{
Sergey Dmitrievich Neulybin ${ }^{1}$, Yury Dmitrievich Schitsyn ${ }^{2}$, Dmitriy Sergeevich Belinin ${ }^{2}$, \\ Gleb L'vovich Permyakov ${ }^{2}$ \\ ${ }^{1}$ Institute of Continuous Media Mechanics of the Ural Branch of Russian Academy of Science, Russia \\ ${ }^{2}$ Perm National Research Polytechnic University, Russia
}

\begin{abstract}
This paper presents the results of producing multilayer blanks and laminates, formation of structure and properties of homoand heterogeneous materials using plasma surfacing at straight and reverse polarity current. Formation of blanks using plasma surfacing was carried out on universal CNC stand developed for this purpose that enables to manufacture blanks of various profiles and complex configurations, including three-dimensional models. Complex metallographic, durometric studies, as well as mechanical tests and research on the operational properties of the obtained samples, were performed.

It is shown that plasma surfacing at reverse polarity current ensures a good fusion of the layers with minimal heat input into the base and filler material. This reduces the thickness of the fusion zone and intermixing of metal in the layers. In addition, cathode cleaning lowers the probability of interlayer defects.

The work presents technology of heterogeneous laminated material creation from combinations of materials: steel (10Cr18Ni10Ti) - nickel alloy (06Cr15Ni60Mo15), steel 10Cr18Ni10Ti - copper (Cu1), steel (38Cr2Ni2MoA) bronze (Al-Mn 9-2).

Received technological recommendations can be applied in various industries in manufacturing parts of complex shapes of both homogeneous and heterogeneous composition.
\end{abstract}

Key words: Plasma technologies, plasma torch, layered materials, microstructure, plasma surfacing, direct polarity of current, reverse polarity of current, structural alloys, mechanical properties.

\section{INTRODUCTION}

Modern industry development is associated with the development of new materials and introduction of innovative technologies and equipment. According to literature by Frazier [1], Petrick and Simpson [2] and Zlenko [3] one of the ways to increase production efficiency of finished metal products of complex shape and size in conditions of a single and small-scale production lies in manufacturing blanks using layer-by-layer metal deposition - additive technologies.

In addition, possibility of using different materials in layers makes it possible to improve performance characteristics of working surfaces operating under severe conditions and to increase the load-bearing capacity of the structure as a whole. Books by Wray [4], Morrow [5], Freedman [6], Chumakov [7], show that the use of such technologies for manufacturing metal structures will increase efficiency and reduce costs for preproduction and finishing machining in manufacturing of critical products of complex shape.

Manufacturing process is a layer-by-layer application of the metal. A paper by Smirnov [8] reviews that surfacing technologies have great opportunities for producing metal blanks. For this purpose, theoretically, all known surfacing technologies can be used. Smirnov [8], Techel et. al. [9], Murr et al. [10], Campanelli et al., Campanelli et al. [11, 12], Chen [13], Ding et al. [14], Williams et al. [15] provide examples of using powder and wire materials for metal products production using additive technologies.

Production of blanks with minimum machining allowance and high service characteristics is associated with solution of a large number of different tasks related to ensuring the accuracy of blanks, such as: the accuracy of the trajectory of the working tool, the provision of a given thickness and profile of the elements, getting specified structure and properties of the construction metal (depth penetration, size of the fusion zone between the layers, metal heating and cooling rate, the residence time of metal in the molten state, chemical composition of metal of layers, possible loss of alloying elements. In addition, it is necessary to take into account cyclic nature of heating of the formed blank that can make it difficult to receive required dimensions of deposited layers and required structure of produced metal.

Ashan M. N. et al. [16], Jhavar [17] describe that surfacing using concentrated energy sources technologies provide wide possibilities for solving the above-mentioned problems.

Currently, successful attempts are being made to use laser powder and electron beam surfacing for manufacturing critical structures from various materials.

Loeber et al. [18], Bezobrazov [19], Louvis et al. [20] believe that along with undeniable advantages, laser additive 
technologies have a number of significant drawbacks: low process efficiency, residual porosity in the processing of active materials and alloys, high requirements for powder dispersion and high equipment cost.

Shchitsyn [21] considers that using plasma surfacing provides a number of advantages, both from the technological and economic point of view. Also Shchitsyn [22] mentions including high efficiency, a wide range of regulation of heat transfer to the base and deposited material and, consequently, control of depth and width of penetration, structure, composition and properties of the material being formed. Wire, powders or their combination can be used as a filler material.

In addition, comparative simplicity and low cost of equipment for plasma surfacing should arouse interest of production workers. Plasma surfacing technologies make it possible to obtain materials with gradient characteristics.

For introduction these technologies into production, it is necessary to develop the technology for manufacturing blanks for critical structures from homo- and heterogeneous laminates using plasma surfacing.

The purpose of this study was to assess manufacturing capability of producing laminates and to determine current polarity effect of on the structure, performance properties of samples obtained with multilayer plasma surfacing.

To achieve this goal, the following tasks were set:

1. To perform comparative studies of formation of the structure and properties of homo- and heterogeneous laminates by plasma surfacing at straight and reverse polarity current;

2. To develop technological recommendations for producing laminates from high-alloy steels and non-ferrous alloys by plasma surfacing.

\section{RESEARCH METHODOLGY}

Work on blanks formation using plasma surfacing was carried out on a universal stand designed for this purpose (Figure 1) that enables producing blanks of various profiles.

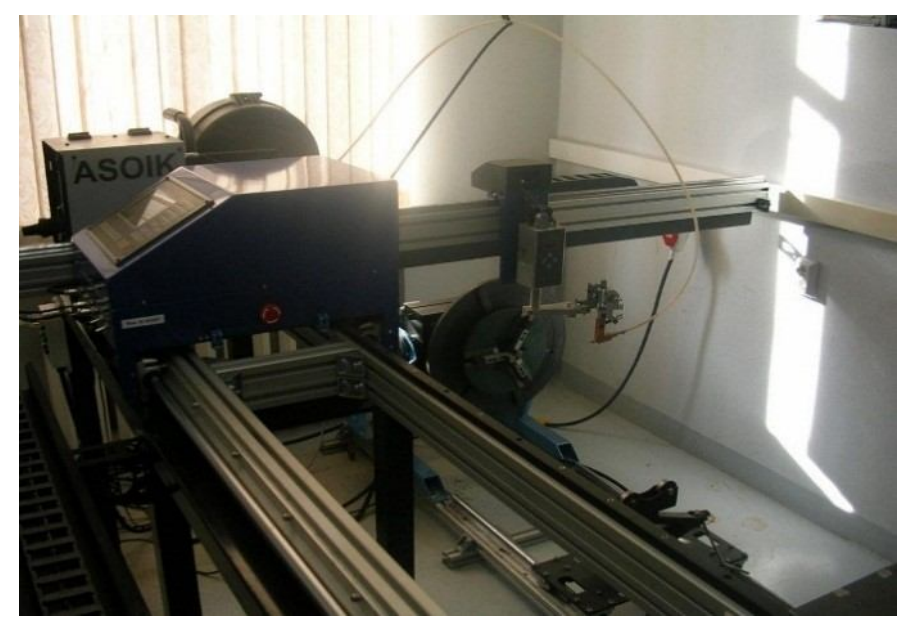

Figure 1: The particles of the universal plasma surfacing stand
The equipment provides maintenance of regime parameters, with a maximum deviation up to $5 \%$. The accuracy of travel is $0.5 \mathrm{~mm}$, and the error in travel speed of working tool is not more than $3 \%$.

Technical parameters are shown in Table 1.

Table 1: Technical characteristics of the plasma surfacing stand

\begin{tabular}{|c|c|}
\hline Travel speed, idling & Up to $8000 \mathrm{~mm} / \mathrm{min}$ \\
\hline Control step of travel speed & $1 \mathrm{~mm} / \mathrm{min}$ \\
\hline Processing area & $1500 \times 500 \mathrm{~mm}$ \\
\hline Rotator load capacity & Up to $600 \mathrm{~kg}$ \\
\hline Faceplate rotating speed & $0,12 \ldots 2,5 \mathrm{rpm}$ \\
\hline Welding current regulating range & $5 \ldots 400 \mathrm{~A}$ \\
\hline Idling voltage & $92 \mathrm{~V}$ \\
\hline Wire feed speed & $0,1 \ldots 18 \mathrm{~m} / \mathrm{min}$ \\
\hline Control step of wire feed speed & $0,01 \mathrm{~m} / \mathrm{mim}$ \\
\hline
\end{tabular}

\subsection{Materials}

The choice of materials results from contractual works performance for military-industrial complex enterprises.

As base materials for samples production, wire materials were used:

- High-alloy steel $10 \mathrm{Cr} 18 \mathrm{Ni} 10 \mathrm{Ti}(\varnothing 1,2 \mathrm{~mm}$, Wire made of high-alloy corrosion-resistant and heat-resistant steel);

- Bronze of grades CuSi3Mn1 and Al-Mn 9-2 (Ø1.6mm, bronzes are thinless, processed by pressure)

- copper grade M1 (Ø1,2mm, Wires and rods of copper and copper-based alloys);

- Nickel alloy 06Cr15Ni60Mo15 (Ø1,2mm, Welding steel wire).

The substrate material used:

- High-alloy steel 10Cr18Ni10Ti (Graded and calibrated steel, corrosion-resistant, heat-resistant).

- steel 38Cr2Ni2MoA (rolling from alloy steel structural steel, Technical specifications).

As a protective and plasma-forming gas, argon was used (argon is gaseous and liquid.) Technical specifications.

\subsection{Structural study of materials}

The methods for structural studies in the work were chosen based on need to analyze materials at various scale levels. Experimental data obtained using these methods was used to illustrate mechanical properties of materials. Metallographic studies were carried out on a digital microscope Altami, a stereoscopic microscope CM0745-T. The images were taken in magnification range from $\mathrm{x} 25$ to $\times 1000$ times. The objects of studying were metallographic sections prepared according to standard methods using PRESIDON-ML-L1 automatic press and PLATO_HA grinding and polishing unit. The cutting operation was performed on a wire EDM machine.

Grinding and polishing of metallographic sections were carried out gradually, consistently increasing the dispersion 
of abrasive materials. Coarse grinding was carried out on abrasive wheels with a grain size of 110 and 22 microns, fine grinding and polishing on cloth circles using diamond suspensions containing particles ranging in size from 9 to 0.5 microns.

Mechanical properties of the material are quantitative indicators that allow evaluating the behavior of a material under external loading conditions. In the presented study, the hardness, strength and ductility under tensile conditions and the toughness of considered materials were evaluated. Measuring microhardness method was used to assess the hardness of structural constituents included in the analysis of materials. The investigations were carried out on microdurometer Wolpert Group 402 MVD according to Vickers method in accordance with the requirements. The indenter was a regular tetrahedral diamond pyramid with an angle of $136^{\circ}$ between opposite faces. The load on the indenter was $0.098 \ldots 1.96 \mathrm{~N}$. Microhardness was evaluated on unetched and slightly etched sections prepared according to a standard procedure. The results of the tests were subjected to statistical treatment. Strength characteristics of layered metal composite materials were determined by the uniaxial stretching scheme in accordance on Instron 3369. The test samples were prepared on a wire EDM machine. Moving of the movable cross-arm of the stretching machine was carried out at speed of $0.5 \ldots 5 \mathrm{~mm} / \mathrm{min}$.

\subsection{Impact bending tests}

In conditions of operation, allowing dynamic impact on structural elements, an important role is played by cracks, incisions and other defects that are mechanical stresses concentrators laminated materials were tested for impact bending. Metrocom impact pendulum-type testing machine was used for the tests with a maximum impact energy of $300 \mathrm{~J}$. The samples were in form of parallelepipeds $10 \times 10 \times 55 \mathrm{~mm}$ in size with U-shaped concentrators. The depth of the incisions was $2 \mathrm{~mm}$. The impact strength of layered composite materials depends to a large extent on direction of application of the load relative to the interface joint of the layers.

\subsection{Corrosion tests}

In aggressive environment working conditions, the material must meet the requirements for corrosion resistance: Methods of corrosion testing. Samples were prepared and tests were carried out by immersion in $\mathrm{HCl}$ and $\mathrm{HNO}_{3}$ solutions of the corresponding materials. To accelerate the corrosion process, it is allowed to conduct testing at elevated temperatures and in the concentration of solutions. The test temperature for $100 \% \mathrm{HNO}_{3}$ solution is $60^{\circ} \mathrm{C}, 100 \% \mathrm{HCl}$ solution is $65^{\circ} \mathrm{C}$. A quantitative estimate was the relative loss of sample mass and sizing them before and after the test. The weighing was carried out on electronic scales ED-H, with an accuracy of 0.001 units.

\subsection{Friction coefficient tests}

To conduct comparative tests of welded layer quality, it is necessary to conduct studies on wear resistance of the working surface. Methods for assessing wear resistance of the restored parts, an assessment of wear resistance is made. A quantitative estimate was the relative weight loss of the sample. The weighing was carried out on electronic scales ED-H, with an accuracy of 0.001 units. Testing time 15 minutes, every 5 minutes the control weight was measured. Washing and drying of the samples were carried out before each weighing.

\section{RESULTS AND ITS CONSIDTERATION}

Currently, more than $80 \%$ of plasma surfacing work is performed at straight polarity current. At the same time, a completely acceptable quality of welded metal is ensured. The book by Shchitsyn (2017) shows that plasma surfacing at reverse polarity current provides good fusion of the layers with minimal heat input into base and filler material. This reduces the thickness of fusion zone and intermixing of the metal in the layers. In addition, cathode cleaning lowers the probability of appearance of interlayer defects. The surfacing microstructures are presented in Figure 2.

(a)

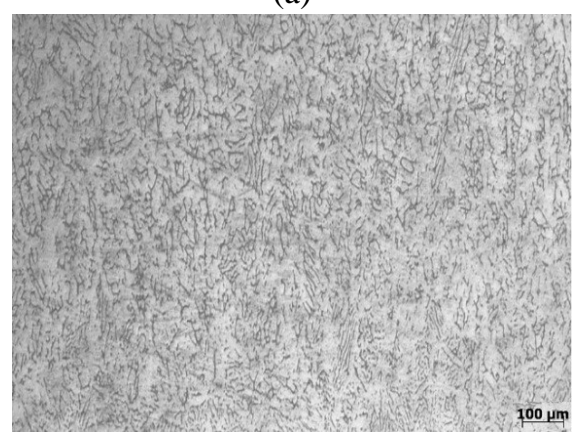

(b)

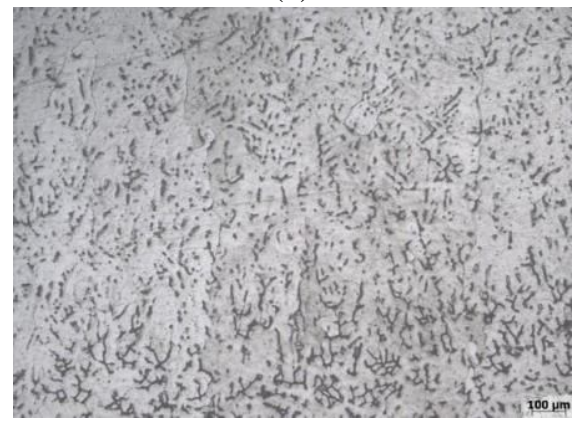

Figure 2: Microstructure of multilayer surfacing of steel 10Cr18Ni10Ti: (a) reverse current polarity, (b) straight current polarity 
During metallographic study of surfacing at reverse polarity current, a transition zone with a thickness of up to $100 \mu \mathrm{m}$ is formed in the area of the first deposited layer (Fig. 2 , a). The structure of the first and second layer of surfacing has a dendritic structure with mutual germination of grains from one layer to another with an increased carbide heterogeneity. Particles of carbides are located, as a rule, along grain boundaries.

The structure of surfacing made by direct action plasma arc with straight polarity is uneven in height (Figure 2, b). In the first layers of surfacing with a height of $3,5 \ldots 3,7 \mathrm{~mm}$, the structure is fine-crystalline, cellular-dendritic character is austenite + carbides with a significant content of $\delta$-ferrite discharge. Next, there is a layer of surfacing with a fine-crystalline structure with a smaller content of $\delta$-ferrite retained. In the rest of surfacing layers $(14.2 \ldots 15 \mathrm{~mm}$ high), a coarse-crystalline structure of elongated dendrites is formed with formation of primary grain boundaries, the structure is austenite + carbides, $\delta$-ferrite discharge are single; In area of coarse-grained structure of the welded metal, hot cracks are formed along the boundaries of the primary grains.

In the work, laminated homogeneous material was tested for tension, impact bending with U-shaped concentrators (Table 2), were tasted 10 samples.

Table 2: Mechanical properties of laminate materials

\begin{tabular}{|c|c|c|c|}
\hline Material & $\sigma_{\mathrm{B}}, \mathrm{MPa}$ & $\sigma_{0.2}, \mathrm{MPa}$ & $\mathrm{KCU}, \mathrm{J} / \mathrm{cm}^{2}$ \\
\hline $10 \mathrm{Cr} 18 \mathrm{Ni10Ti}$ & $535 \ldots 564$ & $210 \ldots 239$ & $200 \ldots 229$ \\
\hline $\begin{array}{c}\text { Laminated } \\
\text { homogeneous material } \\
\text { (straight polarity } \\
\text { current) }\end{array}$ & $526 \ldots 554$ & $220 \ldots .249$ & $125 \ldots 154$ \\
\hline $\begin{array}{c}\text { Laminated } \\
\text { homogeneous material } \\
\text { (reverse polarity current) }\end{array}$ & $517 \ldots 546$ & $235 \ldots 264$ & $145 \ldots 174$ \\
\hline
\end{tabular}

Many products that work in severe conditions are manufactured combined: the base that fulfills bearing properties consists of cheaper materials, and working surfaces that are obtained by depositing alloys with special properties. Studies were carried out on creation of a laminate based on high-alloy steel 10Cr18Ni10Ti and nickel alloy 06Cr15Ni60Mo15. Surfacing was carried out on reverse polarity current in the following sequence: 4 layers of $10 \mathrm{Cr} 18 \mathrm{Ni10Ti}$ steel were deposited on a substrate of $09 \mathrm{Mn} 2 \mathrm{Si}$ steel, consisting of 3 overlapping each other for $30 \%$ rollers. A wide range of control parameters for surfacing allows achieving a minimum transition zone between heterogeneous materials (Figure 3).

(a)

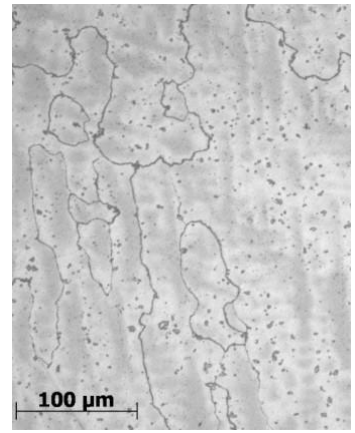

(b)

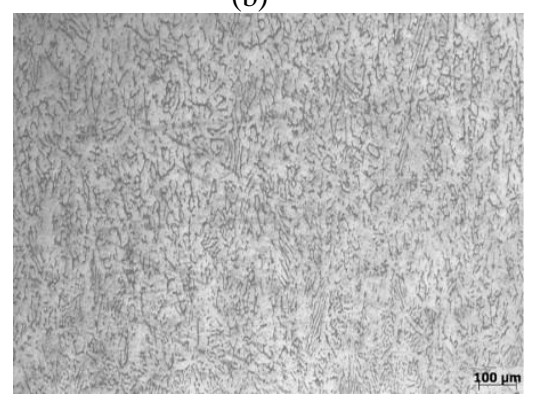

Figure 3: The layers microstructure of the obtained material (X100): (a) a layer of alloy 06Cr15Ni60Mo15, (b) a layer of steel $10 \mathrm{Cr} 18 \mathrm{Ni} 10 \mathrm{Ti}$

Microstructural analysis showed:

- metal of both layers of surfacing is dense, without cracks, pores, looseness, incomplete fusion and oxide blisters;

- in the first layer of surfacing the structure is dendritic, the axes of the first and second order dendrites are thin; in the interdendritic space there are multiple discharges of fine particles typical for nickel alloys of the second $\gamma$ 'phase in the form of stitches.

Results of mechanical properties of the obtained laminate are shown in Table 3.

Table 3: Mechanical properties

\begin{tabular}{|c|c|c|c|c|}
\hline Material & $\sigma_{\mathrm{B}}, \mathrm{MPa}$ & $\sigma_{0,2}, \mathrm{MPa}$ & $\delta, \%$ & $\begin{array}{c}\mathrm{KCU}, \\
\mathrm{J} / \mathrm{cm}^{2}\end{array}$ \\
\hline 10Cr18Ni10Ti & $543 \ldots 550$ & $221 . .228$ & $45 \ldots 48$ & $214 \ldots 217$ \\
\hline 06Cr15Ni60Mo15 & $674 \ldots 685$ & $416 \ldots 430$ & $33 \ldots 35$ & $143 \ldots 145$ \\
\hline Laminated material & $538 . .556$ & $390 \ldots 396$ & $21 \ldots 25$ & $149 \ldots 152$ \\
\hline
\end{tabular}

Based on the results of the study, the following results were obtained for corrosion resistance of samples made with multilayer plasma surfacing at straight and reverse polarity currents. General corrosion rate of a sample of high-alloy steel $10 \mathrm{Cr} 18 \mathrm{Ni} 10 \mathrm{Ti}$ welded at straight polarity current was $0.00082 \mathrm{~g} /(\mathrm{m} 2 \cdot \mathrm{h})$, corrosion of a sample of high-alloy steel $10 \mathrm{Cr} 18 \mathrm{Ni} 10 \mathrm{Ti}$ welded at reverse polarity current was 0.0007 $\mathrm{g} /(\mathrm{m} 2 \cdot \mathrm{h})$, corrosion of a sample of alloy $06 \mathrm{Cr} 15 \mathrm{Ni} 60 \mathrm{Mo} 15$ $+10 \mathrm{Cr} 18 \mathrm{Ni10Ti}$ was $0.0004 \mathrm{~g} /(\mathrm{m} 2 \cdot \mathrm{h})$,

Figure 4 shows structure of plasma surfacing of copper $(\mathrm{Cu} 1)$ on steel $(10 \mathrm{Cr} 18 \mathrm{Ni10Ti})$ at straight and reverse polarity current. 
(a)

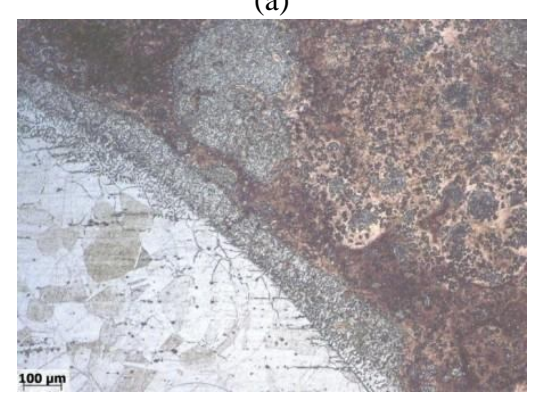

(b)

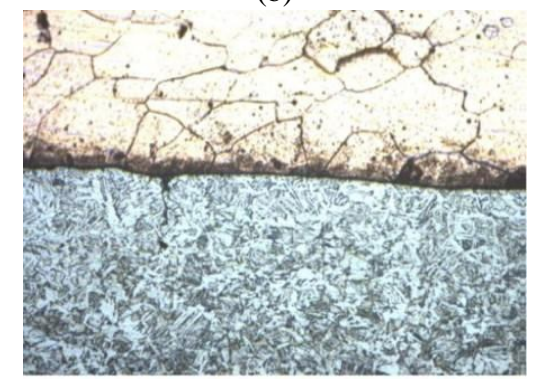

Figure 4: The microstructure of the laminate steel (10Cr18Ni10Ti) - copper (Cu1): (a) surfacing at straight current polarity, (b) surfacing at a reverse current polarity

Metallographic analysis shows that surfacing of one roller at straight polarity current is up to $2.2 \mathrm{~mm}, 13 \mathrm{~mm}$ wide. The depth of penetration into the base was up to $2.1 \mathrm{~mm}$. When surfacing at reverse polarity current geometric dimensions of one roller are width $23 \mathrm{~mm}$; height $3 \mathrm{~mm}$. The depth of penetration was up to $0.3 \mathrm{~mm}$. Metal $10 \mathrm{Cr} 18 \mathrm{Ni10Ti}$ has a fine-crystalline structure. The structure is cellular-dendritic in nature based on austenite with discharge of $\delta$-ferrite along crystallite boundaries + carbides that is typical for cast state of welded metal.

To ensure increased corrosion and wear resistance of the surface prepared for surfacing, bronzes of different composition are used. The possibility of surfacing bronzes of Al-Mn 9-2 on $38 \mathrm{Cr} 2 \mathrm{Ni} 2 \mathrm{MoA}$ steel is shown in the work. During surfacing, improved steel was used that underwent hardening $850^{\circ} \mathrm{C}$ in oil for 1 hour + tempering $650^{\circ} \mathrm{C}$ for 1.5 hours, with a hardness of at least $270 \mathrm{HB}$ ).

Surfacing microstructure is shown in Figure 5.

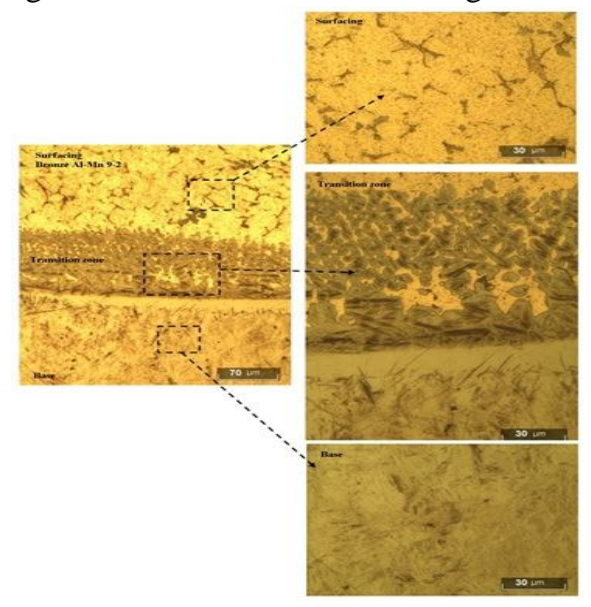

(a)

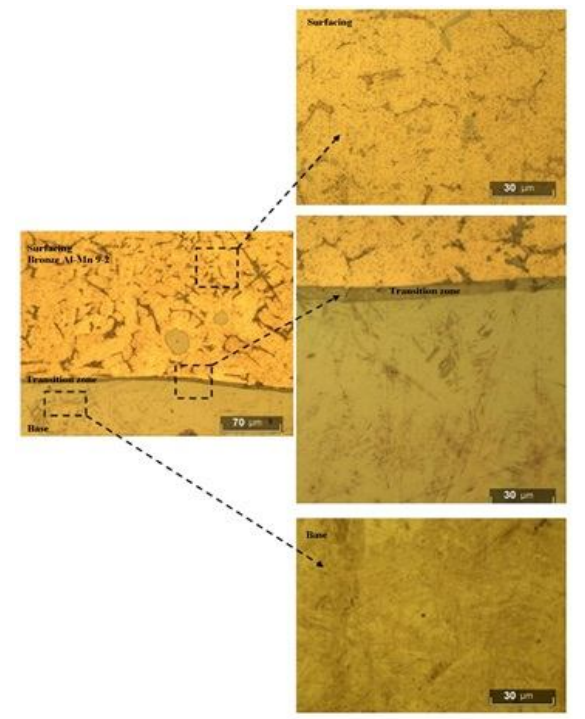

(b)

Figure 5: The microstructure and characteristic zones of surfacing Bronze Al-Mn 9-2: (a) straight polarity current, (b) reverse polarity current

Microstructural analysis of plasma surfacing at direct polarity current has shown that surfacing metal does not have incomplete fusion, pores, blisters, cracks; the structure of surfacing consists of an $\alpha$-solid solution; the transition zone has a non-uniform width of 0.015 to $0.125 \mathrm{~mm}$ with a cellular-dendritic structure. When surfacing at reverse polarity of current, a defectless structure of deposited layer is obtained, consisting of an $\alpha$-solid solution; at the fusion line of bronze surfacing with steel there is a typical transition zone of $0.005 \ldots 0.01 \mathrm{~mm}$ in width made of steel with bronze inclusions.

Microhardness of typical deposition zones is shown in Table 4.

Table 4: Microhardness of typical deposition zones

\begin{tabular}{|c|c|}
\hline Measurement zone & $\begin{array}{c}\text { Microhardness, H } \mu 50, \\
\mathrm{kgs} / \mathrm{mm} 2\end{array}$ \\
\hline Base material & $270 \ldots 310$ \\
\hline HAZ & $310 \ldots 514$ \\
\hline Br Al-Mn 9-2 surfacing & $160 \ldots 187$ \\
\hline
\end{tabular}

Efficiency of the welded working surface obtained was evaluated by friction tests using pin-on-disk method in a chromium-bronze pair. Test results are shown in Table 5.

Table 5: The values of friction coefficients of chromium and bronze pair

\begin{tabular}{|c|c|c|c|}
\hline \multirow{2}{*}{ Sample } & \multicolumn{3}{|c|}{ Measurement } \\
\hline & 1 & 2 & 3 \\
\hline $\begin{array}{c}\text { Br Al-Mn 9-2 (surfacing at reverse polarity } \\
\text { current) }\end{array}$ & 0,51 & 0,66 & 0,53 \\
\hline \multicolumn{4}{|c|}{$\begin{array}{c}* \text { friction coefficients of chromium-bronze in initial state: } 0,5 \\
* * \text { test conditions: } V=1 \mathrm{~m} / \mathrm{s}, P=3 \mathrm{MPa}\end{array}$} \\
\hline
\end{tabular}




\section{CONCLUSION}

1. Possibility of creating layered materials by plasma surfacing on plasmatron operation at straight and reverse polarity current is estimated.

2. It is established that the use of reverse polarity makes it possible to obtain a defectless, finer-dispersed structure in case of multilayer surfacing of high-alloy steel $10 \mathrm{Cr} 18 \mathrm{Ni} 10 \mathrm{Ti}$.

3. Technology of manufacturing heterogeneous laminated material from combinations of materials is developed: steel (10Cr18Ni10Ti) - nickel alloy (06Cr15Ni60Mo15), steel $10 \mathrm{Cr} 18 \mathrm{Ni10Ti}$ - copper (Cu1), steel (38Cr2Ni2MoA) bronze (Al-Mn 9-2).

4. It is shown that the use of reverse polarity current allows reducing general corrosion rate with respect to surfacing at straight polarity current of high-alloy steel up to $10 \%$, and the use of bimetal allows reducing corrosion rate to $50 \%$.

5. It is experimentally confirmed that wear resistance of welded working surface is not inferior to wear resistance of bronze in the initial state.

\section{ACKNOWLEDGEMENT}

The reported study was funded by RFBR, project number No 19-38-60043\19, and The work was carried out with the financial support of the Ministry of Education and Science of the Russian Federation FSNM-2020-0028.

\section{REFERENCES}

1. W. E. Frazier. Metal Additive Manufacturing: A Review, Journal of Materials Engineering and Performance, Vol. 23, No 6, pp. 1917-1928, 2014. DOI: https://doi.org/10.1007/s11665-014-0958-z

2. I. J. Petrick and T. W. Simpson. 3D Printing Disrupts Manufacturing: How Economies of One Create New Rules of Competition, Research-Technology Management, Vol. 56, No 6, pp. 15-16, 2013. DOI: $10.5437 / 08956308 \times 5606193$

3. M. A. Zlenko, M. V. Nagaitsev and V. M. Dovbysh. Additivnye tekhnologii $\mathbf{v}$ mashinostroenii. Posobie dlya inzhenerov. Izdatel'stvo GNTs RF FGUP "NAMI", Moscow, 2015, 220 p. (in Russian).

4. P. Wray. Additive Manufacturing: Turning Manufacturing Inside Out, American Ceramic Society Bulletin, Vol. 93, No 3, pp. 17-23, 2014. http://ceramics.org/wp-content/uploads/2009/06/Apr14_ cover-story.pdf

5. W. R. Morrow, H. Qi, I. Kim, J. Mazumder and S. J. Skerlos. Environmental Aspects of Laser-Based and Conventional Tool and Die Manufacturing, Journal of Cleaner Production, Vol. 15, No 10, pp. 932-943, 2007. DOI: https://doi.org/10.1016/j.jclepro.2005.11.030

6. D. H. Freedman. Layer by Layer, Technology Review, Vol. 115, pp. 50-53, 2012.
7. D. M. Chumakov. Perspektivy ispol'zovaniya additivnykh tekhnologii pri sozdanii aviatsionnoi i raketno-kosmicheskoi tekhniki, Elektronnyi zhurnal "Trudy MAI", Vol. 78, pp. 1-22, 2014 (in Russian). http://trudymai.ru/upload/iblock/e6e/ e6ed6634d88fd08e030a8736e3f845e4.pdf

8. V. V. Smirnov, V. V. Barzali and P. V. Ladnov. Perspektivy razvitiya additivnogo proizvodstva $v$ rossiiskoi promyshlennosti. Opyt FGBOU UGATU (obzor), Novosti materialovedeniya, Nauka i tekhnika, Vol. 2, No 14, pp. 23-27, 2015 (in Russian). http://materialsnews.ru/plugins/cont ent/journal/uploads/articles/pdf/127.pdf

9. A. Techel, F. Brückner, S. Nowotny, R. Wappler, S. Scharek, F. Kubisch, S. Bonß and E. Beyer. Laser additive manufacturing of turbine components, precisely and repeatable, Fraunhofer Institute for Material and Beam Technology (IWS). http://www.lia.org/blog/category/laser-insights-2/laser-a dditivemanufacturing/

10. L. Murr, S. Gaytan, D. A. Ramirez, E. Martinez, J. Hernandez, K. N. Amato, P. W. Shindo, F. Medina and R. B. Wicker. Metal fabrication by additive manufacturing using laser and electron beam melting technologies, Journal of Materials Science \& Technology, Vol. 28, No 1, pp. 1-14, 2012. DOI: https://doi.org/10.1016/S1005-0302(12)60016-4

11. S. L. Campanelli, N. Contuzzi, A. Angelastro and A. D. Ludovico. Capabilities and Performances of the Selective Laser Melting Process, New Trends in Technologies: Devices, Computer, Communication and Industrial, Systems, Vol. 13, pp. 233-253, 2010. DOI: 10.5772/10432. http://cdn.intechopen.com/ pdfs/12285/InTechCapabilities_and_performances_of_t he_selective_laser_melting_process.pdf

12. S. L. Campanelli, N. Contuzzi and A. D. Ludovico. Manufacturing of $18 \mathrm{Ni}$ Marage 300 steel samples by selective laser melting, Advanced Materials Research, Vol. 83-86, pp. 850-857, 2010. DOI: 10.4028/www.scientific.net/AMR.83-86.850

13. J. Chen. Hybrid design based on wire and arc additive manufacturing in the aircraft industry. Research Thesis. Cranfield University, UK, 2012, 163p. http://dspace.lib.cranfield.ac.uk/handle/1826/7863

14. D. Ding, Z. Pan, D. Cuiuri and H. Li. Wire-feed additive manufacturing of metal components: technologies, developments and future interests, The International Journal of Advanced Manufacturing Technology, Vol. 81, No 1-4, pp. 465-481, 2015. DOI: https://doi.org/10.1007/s00170-015-7077-3

15. S. W. Williams, F. Martina, A. C. Addison, J. Ding, G. Pardal and P. Colegrove. Wire + Arc Additive Manufacturing, Materials Science and Technology, Vol. 32, No 7, pp. 641-647, 2016. DOI: http://dx.doi.org/10.1179/1743284715Y.0000000073

16. M. N. Ahsan, A. Pinkerton and L. Ali Ali. A comparison of laser additive manufacturing using gas and 
plasma-atomized Ti-6Al-4V powders. In the book "Innovative Developments in Virtual and Physical Prototyping" (J. Dias, P. Bártolo, N. Alves, R. Pereira, T. Patrício), Taylor \& Francis Group, London. pp. 625-633, 2012. DOI: https://doi.org/10.1201/b11341-100

17. S. Jhavar, N. K. Jain and C. P. Paul. Development of micro-plasma transferred arc $(\mu$-PTA $)$ wire deposition process for additive layer manufacturing applications, Journal of Materials Processing Technology, Vol. 214, No 5, pp. 1102-1110, 2014. DOI: https://doi.org/10.1016/j.jmatprotec.2013.12.016

18. P. L. Loeber, S. Biamino, U. Ackelid, S. Sabbadini, P. Epicoco, P. Fino and J. Eckert. Comparison of selective laser and electron beam melted titanium aluminides. 22nd Annual International Solid Freeform Fabrication Symposium - An Additive Manufacturing Conference, Austin, pp. 547-556, 2011.

http://sffsymposium.engr.utexas.edu/Manuscripts/2011/ 2011-43-Loeber.pdf

19. Yu. A. Bezobrazov, M. A. Zlenko, O. G. Zotov and N. G. Kolbasnikov. Analiz struktury obraztsov, poluchennykh DMLS- i SLM- metodami bystrogo prototipirovaniya. In "Materialy 6-i mezhdunarodnoi molodezhnoi nauchno-prakticheskoi konferentsii "Innovatsionnye tekhnologii v metallurgii i mashinostroenii. Ural'skaya nauchno-pedagogicheskaya shkola imeni professora A. F. Golovina”, Ural University Publishing Houseб Ekaterinburg. pp. 154-157, 2012 (in Russian).

http://elar.urfu.ru/bitstream/10995/33259/1/itvmim_201 2_28.pdf

20. E. Louvis, P. Fox and Ch. J. Sutcliffe. Selective laser melting of aluminium components, Journal of Materials Processing Technology, Vol. 211, No 2, pp. 275-284, 2011.

DOI: https://doi.org/10.1016/j.jmatprotec.2010.09.019

21. Yu. D. Shchitsyn, O. A. Kosolapov and V. Yu. Shchitsyn. Vozmozhnosti plazmennoi obrabotki metallov tokom obratnoi polyarnosti, Svarka. Diagnostika, Vol. 2, pp. 42-45, 2009 (in Russian).

22. Yu. D. Shitsyn, D. S. Belinin and S. D. Neulybin. Plasma Surfacing Of High-Alloy Steel 10Cr18Ni8Ti On Low-Alloy Steel 09Mg2Si, International Journal of Applied Engineering Research, Vol. 10, No 20, pp. 41103-41109, 2015. 